\title{
Pleistocene expansion, anthropogenic pressure and ocean currents: Disentangling the past and ongoing evolutionary history of Patella aspera Röding, 1798 in the archipelago of Madeira
}

\author{
Ricardo Sousa $^{\text {a,b,c }}$, Joana Vasconcelos ${ }^{\text {c, d,e }}$, Iván Vera-Escalona ${ }^{\text {f,g }}$, Ana Rita Pinto ${ }^{\mathrm{b}}$, S. \\ J. Hawkins ${ }^{\text {h,i }}$, Mafalda Freitas ${ }^{\mathrm{a}, \mathrm{b}, \mathrm{c}}$, João Delgado ${ }^{\mathrm{b}, \mathrm{j}}$, José A. González ${ }^{\mathrm{k}}$, Rodrigo Riera ${ }^{\text {e,g,* }}$ \\ a Observatório Oceânico da Madeira, Agência Regional para o Desenvolvimento da Investigação Tecnologia e Inovação (OOM/ARDITI) - Edifício Madeira Tecnopolo, \\ Funchal, Madeira, Portugal \\ b Direção Regional do Mar (DRM)/ Direção de Serviços de Monitorização, Estudos e Investigação do Mar (DSEIMar), 9004-562, Funchal, Madeira, Portugal \\ ${ }^{\mathrm{c}}$ MARE - Marine and Environmental Sciences Centre, Agência Regional para o Desenvolvimento da Investigação Tecnologia e Inovação (ARDITI), Edifício Madeira \\ Tecnopolo Piso 0, Caminho da Penteada, 9020-105, Funchal, Madeira, Portugal \\ ${ }^{\mathrm{d}}$ Faculdade de Ciências de Vida, Universidade da Madeira, Campus Universitário da Madeira, Caminho da Penteada, 9020-020, Funchal, Madeira, Portugal \\ e Departamento de Ecología, Facultad de Ciencias, Universidad Católica de la Santísima Concepción, Casilla 297, Concepción, Chile \\ ${ }^{\mathrm{f}}$ CIBAS, Facultad de Ciencias, Universidad Católica de la Santísima Concepción, Casilla 297, Concepción, Chile \\ ${ }^{g}$ IU-ECOAQUA, Group of Biodiversity and Conservation (BIOCON), Universidad de Las Palmas de Gran Canaria, Las Palmas de Gran Canaria, Spain \\ ${ }^{\mathrm{h}}$ Marine Biological Association of the UK, Plymouth, PL1 2PB, UK \\ ${ }^{\mathrm{i}}$ School of Ocean and Earth Science, University of Southampton, National Oceanography Centre, Southampton, SO14 3ZH, UK \\ ${ }^{\mathrm{j}}$ Centro Interdisciplinar de Investigação Marinha e Ambiental (CIIMAR/CIMAR), Porto, Portugal \\ ${ }^{\mathrm{k}}$ Ecología Marina Aplicada y Pesquerías (i-UNAT), Universidad de Las Palmas de Gran Canaria, Las Palmas de Gran Canaria, Spain
}

\section{A R T I C L E I N F O}

\section{Keywords:}

Genetic markers

Microsatellites

Limpet

Intertidal

Island

NE Atlantic ocean

\begin{abstract}
A B S T R A C T
Aims: Rising sea-level following the Last Glacial Maximum lead to fragmentation of coastal limpet populations between islands of the Archipelago of Madeira. This fragmentation is reinforced by recent heavy exploitation reducing effective population size on Madeira Island. We use the limpet $P$. aspera to understand how the role of processes at different time scales (i.e. changes in the sea level and overexploitation) can influence the genetic composition of an extant species, relating these processes to reproductive phenology and seasonal shifts in ocean currents.

Location: Madeira Island, Porto Santo and Desertas (Archipelago of Madeira, NE Atlantic Ocean).

Taxon: The limpet Patella aspera.

Methods: Twelve microsatellite genetic markers were used. A power analysis was used to evaluate the power of the microsatellite markers to detect a signal of population differentiation. Long-term past migrations were assessed using a Bayesian Markov Montecarlo approach in the software MIGRATE-n to estimate mutation-scaled migration rates $(M=m / \mu ; m$, probability of a lineage immigrating per generation; $\mu$, mutation rate). Two scenarios were evaluated using an Approximate Bayesian Computation (ABC) in the software DIYABC 2.1 (i) Scenario 1: considered a population scenario from a reduced $N e$ at time $t_{3}$ to a higher $N e$ at time $t_{2}$; and (ii) Scenario 2 considering a reduction of $\mathrm{Ne}$ from a time $\mathrm{t}_{3}$ to a time $\mathrm{t}_{2}$.

Results: Colonization of the archipelago by Portuguese settlers six centuries ago probably led to an important decrease in the genetic diversity of the species $\left(N_{\mathrm{e}}\right)$. Contemporary gene flow strongly support a pattern of high asymmetric connectivity explained by the reproductive phenology of the species and spatio-temporal seasonal changes in the ocean currents. Spatio-temporal reconstructions using Bayesian methods, including coalescent and Approximate Bayesian Computation (ABC) approaches, suggest changes in the migration patterns from highly symmetric to highly asymmetric connectivity with subtle population differentiation as consequence of post-glacial maximum sea level rise during the Holocene.
\end{abstract}

\footnotetext{
* Corresponding author. IU-ECOAQUA, Group of Biodiversity and Conservation (BIOCON), Universidad de Las Palmas de Gran Canaria, Las Palmas de Gran Canaria, Spain.

E-mail address: rodrigo.riera@ulpgc.es (R. Riera).
} 
Main conclusions: Our results suggest that anthropogenic activity could have had serious effects on the genetic diversity of heavily exploited littoral species since the end of the Pleistocene, probably accelerating in recent years.

\section{Introduction}

Quaternary glaciations have shaped a wide number of phylogeographic processes and subsequent biogeographic patterns worldwide (Ehlers et al. 2004, 2011; Marko et al., 2010; Waltari and Hickerson 2013; Ludt and Rocha 2015), such as the closure of the Isthmus of Panama (Stange et al., 2018) and in the North-western Pacific (Cheang et al., 2012). During the decline in the temperatures and the expansion of glaciers occurring in the Quaternary, the landscape and seascape showed major changes, including dropping sea levels and exposure of coastal areas currently under the sea (Clark and Mix 2002; Clark et al., 2009; Lambeck et al., 2014). During the Quaternary, more specifically during the Last Glacial Maximum (LGM; 26500-19000 Kyr BP), the sea retreated over 100 meters below current sea level, connecting previously separated islands and exposing large coastal areas (Pirazzoli 1997; Clark and Mix 2002; Clark 2009). With the melting of the ice and rising sea levels during the Holocene (11500 Kyr BP up the present), previously connected landmasses became isolated, affecting the connectivity of species (Mairal et al., 2015; Patiño et al., 2015; Fernández-Palacios et al., 2016; Weigelt et al., 2016; Dolby et al., 2020).

As consequence of these changes, populations became fragmented, as occurred with some of the islands in the archipelago of Madeira (Rijsdijk et al., 2014; Fernández-Palacios et al., 2016). During the LGM, the archipelago of Madeira comprised two islands, one larger island, that encompassed the current Madeira and Desertas and a smaller island, Porto Santo. The larger island split into two islands (Madeira and
Desertas) when over a short period of $c a .1000$ years during the Holocene, they became separated due to the sea level increase. Porto Santo initially five times larger than at present during the LGM (see Fig. 6 in Rijsdijk et al., 2014), shrank to its present size due to rising sea levels (Fig. 1). Thus, previous studies have quantified the changes in the surface areas of these islands revealing the magnitude of the effects of Quaternary glaciations. To date a few studies using molecular genetic techniques have addressed the effects of these changes over the genetic patterns of patellids at a small scale using allozyme electrophoresis (Weber et al., 1998; Weber and Hawkins, 2002) and microsatellites (Faria et al., 2018).

Changes in the sea level during the past have directly affected the survival and connectivity of species in coastal areas due to the reduction or increase of the availability of habitat (Ludt and Rocha 2015), but also separation of previously connected areas thereby creating new barriers for populations (e.g. Imron et al., 2007; Crandall et al., 2008; Ludt and Rocha 2015). The appearance of these barriers can have from profound to no effects on species, depending on the life history traits of the species (Ludt and Rocha 2015). Sessile species reproducing through the release of free propagules and eggs into the ocean seem to have been less affected by Pleistocene-Holocene changes in the sea level (Miller and Ayre 2008; Nuryanto and Kochzius 2009). Nevertheless, the dispersal of these new individuals can also be limited by the direction of ocean currents coupled with the time of reproduction and larval release of a species (Scheltema 1971; Lind et al., 2007; Muñoz-Ramírez et al., 2020).

Therefore, the degree of genetic connectivity among populations of

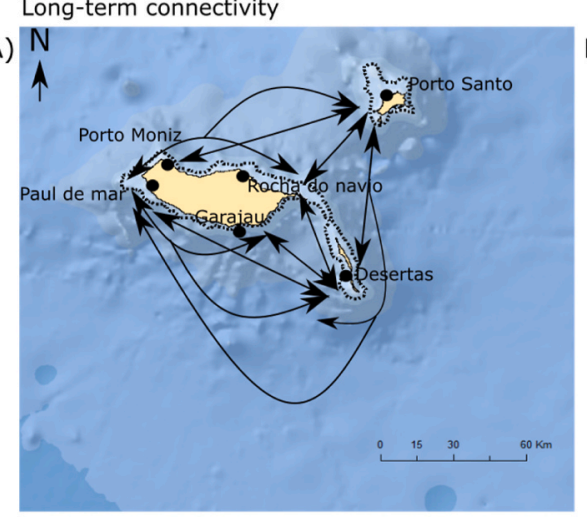

$F_{\mathrm{ST}}$-based population structure

C) $\mathrm{N}$

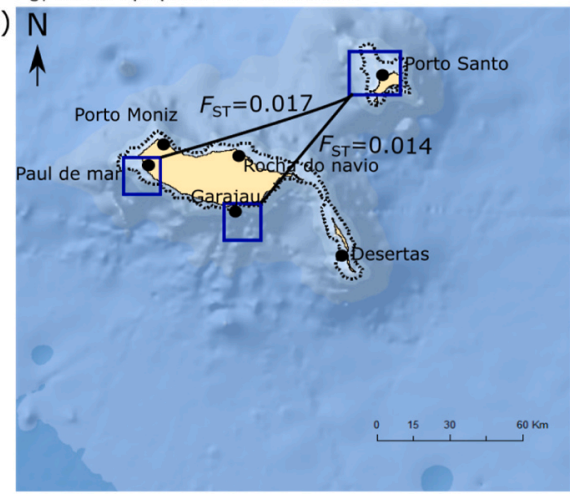

\section{Contemporary connectivity}

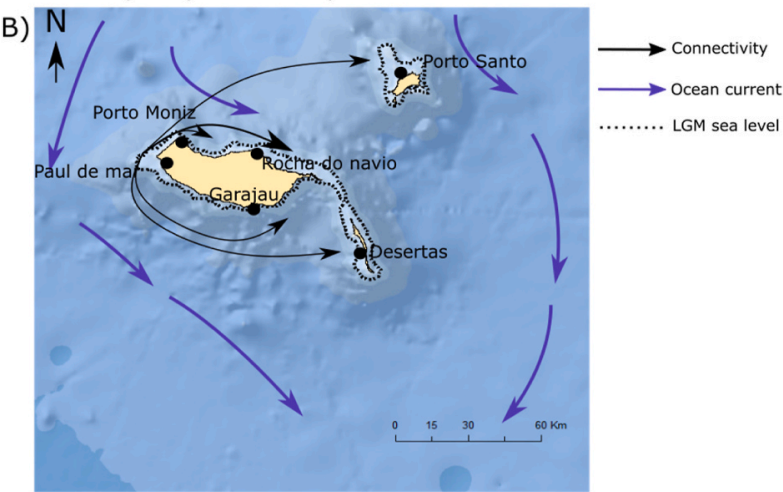

STRUCTURE-based population structure

D) $\mathrm{N}$

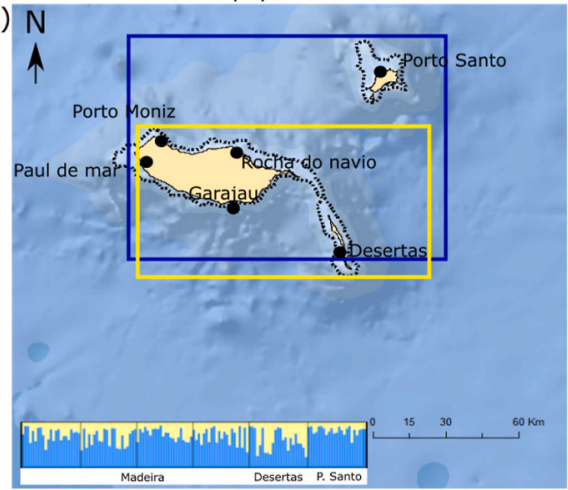

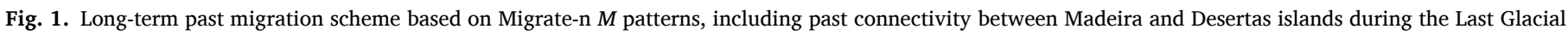

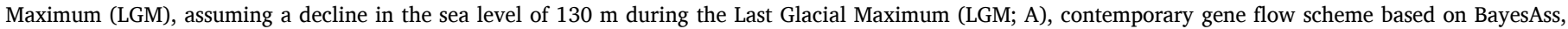

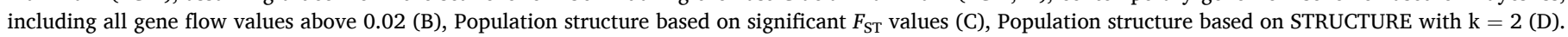


sessile or sedentary coastal species could be explained by both long-term past and contemporary changes in the seascape, combined with life history traits and ocean currents. An accurate knowledge of the extent of genetic exchange and demographic connectivity of populations is not only of fundamental evolutionary biological interest, but also important for their conservation and management if commercially exploited. This is especially true in places like the archipelago of Madeira, where coastal species in the islands have been affected both by changes in habitat extent during the Quaternary glaciations, but also by the anthropogenic pressures since the colonization of the islands six centuries ago by Portuguese settlers (Boehrer 1955; Russell-Wood 2007). Local human populations have consumed Patella aspera Röding, 1798 for centuries probably affecting their population sizes and genetic diversity due to the overexploitation in some areas of the archipelago (Faria et al., 2018; Sousa et al. 2019a, 2019b). Although this has been hypothesized from ecological and morphological studies, this has not been assessed using genetic methods (but see Weber and Hawkins, 2002).

All of these longer-term phylogeographic processes and short-term historical anthropogenic pressures can be explored by genetic markers, including microsatellites (Riginos and Liggins 2013; Selkoe et al., 2016). Microsatellite markers enable understanding of how processes at different time scales have influenced the genetic diversity and structure of populations of a species (Wang 2010). For instance, microsatellite markers have been used to disentangle how changes in the connectivity of species have occurred through time as a consequence of habitat modifications by natural (Faria et al., 2017) and anthropogenic factors (e.g. Ngeve et al., 2016; Hernawan et al., 2017; Vera-Escalona et al., 2015; Samarasin et al., 2017). One of the advantages of microsatellites markers is that their mutation rate can help us to reveal processes that have occurred both thousands of years ago (e.g. Pleistocene), as well as up to just a few generations before present (Holocene-Anthropocene; Wang 2010). Bayesian methods, including coalescent and Approximate Bayesian Computation (ABC) approaches allow disentangling the combined signal of processes acting at different time scales to test hypotheses about how changes in the landscape during the past have affected exchange within meta-population networks and effective population sizes.

Conservation measures can only be implemented successfully with knowledge of the genetic diversity of species plus structure of populations in the context of the evolutionary processes generating them (Groom et al., 2006; Allendorf 2017; Holderegger et al., 2019). Therefore, an evolutionary perspective on changes in the genetic diversity of species in time and space are crucial for the conservation of species and populations (Fenderson et al., 2020). Contemporary patterns of genetic diversity can be the result of long-term phylogeographic and shorter-term historical processes, including changes in the population sizes, genetic diversity and connectivity (Epps and Keyghobadi 2015; Al-Asadi et al., 2019). Several studies have shown that connectivity patterns among populations have dramatically changed during the Pleistocene-Holocene (e.g., seastars, Crandall et al., 2014; seagrasses, Hernawan et al., 2017; mangroves, Ngeve et al., 2016; sharks, Portnoy et al., 2014). For instance, for marine species, it has been predicted that an increase in the sea level and changes in the ocean currents as consequence of climate change which could lead to new changes in habitat availability of species and negative or positive effects for their reproduction (Scavia et al., 2002; Pecl et al., 2011; Jones and Cheung 2018; Bakare et al., 2020). Therefore, by knowing how species have responded during the past we could be better prepared to decide on what species and locations to prioritize when taking conservation measures (Fenderson et al., 2020).

Here we used the limpet $P$. aspera in the Madeira archipelago (NE Atlantic Ocean) to understand how the role of processes at different time scales (i.e. changes in the sea level and overexploitation) can influence the genetic composition of an extant species, relating these processes to reproductive phenology and seasonal shifts in ocean currents. P. aspera is a slow growth moderately long-lived species, that inhabiting coastal areas from 0 to $6 \mathrm{~m}$ deep (Sousa et al. 2017, 2019). This species maturates with approximately $40 \mathrm{~mm}$ and reaches a maximum longevity of 9 years in Madeira archipelago (Sousa et al., 2017). The release of free eggs for external fertilization mostly occurs between January to April, when the Canaries current moves from West to East, from Madeira Island up to Porto Santo and Desertas Islands, the latter being the last to be connected to Madeira. The limpets of the genus Patella have a planktonic larval stage lasting approximately one to two weeks (Hawkins et al., 2000). The veliger larvae, after remaining in the plankton, settle in the substrate at the lower level of the coast and as they grow they initiate a slow vertical migration, colonizing different levels of the rocky coast (Boaventura et al., 2003). The short duration of larvae combined with the average velocity Azores $\left(10 \mathrm{~cm} \mathrm{~s}^{-1}\right.$ ) (Artamonov et al., 1994) and Canary currents (10-15 $\mathrm{cm} \mathrm{s}^{-1}$ ) (Zhou et al., 2000) prevents the flow of larvae between the Macaronesian archipelagos (Sá-Pinto, 2008).

Our goal was to evaluate whether past changes in sea level and human activity (Portuguese colonization), and recent creation of Marine Protected Areas have had a noticeable effect on genetic structure and connectivity as indicated by neutral microsatellite markers. We hypothesized that rising sea-level following the Last Glacial Maximum would lead to fragmentation of populations with differences being greater the longer the separation had occurred (Porto Santo would be more distinct from Madeira Island than the Desertas). Moreover, we expected that fragmentation would be reinforced by recent heavy exploitation reducing effective population size on Madeira Island.

\section{Materials and methods}

\subsection{Sampling collection and molecular protocols}

Patella aspera were collected from six locations in the islands of Madeira, Desertas, and Porto Santo in the archipelago of Madeira (NE Atlantic Ocean) (Table 1; Fig. 1). Twenty-one to twenty-three individuals of $P$. aspera were collected from each location. A total of 12 microsatellite markers were used for screening as previously conducted by Faria et al. (2017) (see Table S1). DNA was extracted using an E.Z.N. A Mollusc DNA kit (Omega Bio-Tek) following the manufacturer's instructions. Polymerase chain reactions (PCRs) were performed in final reaction volume of $12.5 \mu \mathrm{L}$, containing $1 \mu \mathrm{L}$ of DNA, $6.25 \mu \mathrm{L}$ of the Type-it Microsatellite PCR Kit (Qiagen), $4 \mu \mathrm{L}$ of PCR-grade water, and $1.25 \mu \mathrm{L}$ of the primer mix. The optimal PCR protocol consisted of an initial denaturation step at $95^{\circ} \mathrm{C}$ for $5 \mathrm{~min}$, followed by 30 cycles of 95 ${ }^{\circ} \mathrm{C}$ for $30 \mathrm{~s}, 57^{\circ} \mathrm{C}$ for $90 \mathrm{~s}, 72{ }^{\circ} \mathrm{C}$ for $30 \mathrm{~s}, 8$ cycles of $95^{\circ} \mathrm{C}$ for $30 \mathrm{~s}, 53{ }^{\circ} \mathrm{C}$ for $90 \mathrm{~s}, 72{ }^{\circ} \mathrm{C}$ for $30 \mathrm{~s}$; and final extension step at $68^{\circ} \mathrm{C}$ for $30 \mathrm{~min}$. Alleles were called using Geneious 10.2.3 (Biomatters Ltd) to observe the allelic peaks obtained for each individual. All DNA extractions and microsatellite markers development were performed by Allgenetics using positive and negative controls to check for potential cross-contamination(https://www.allgenetics.eu).

\subsection{Descriptive analyses}

Hardy-Weinberg Equilibrium (HWE) and Linkage Disequilibrium (LD) tests were estimated in Genepop on the web (Rousset 2008; http://genepop.curtin.edu.au/) to assess markers or populations differing from the assumptions made to estimate gene flow among populations. A Bonferroni correction was used to account for multiple tests in both the HWE and LD. Number of alleles $(\mathrm{Na})$, observed heterozygosity $(\mathrm{Ho})$, and expected heterozygosity $(\mathrm{He})$, and Inbreeding coefficients $\left(\mathrm{F}_{\mathrm{IS}}\right.$ ) were calculated in Genalex 6.5 (Peakall and Smouse 2006). Allelic richness $\left(A_{r}\right)$ and private alleles $(P a)$ were calculated using HP-RARE (Kalinowski 2005), to compare the genetic diversity between collection sites using different parameters. 
Table 1

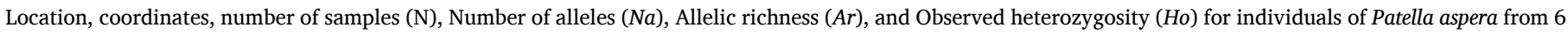
locations in the archipelago of Madeira using 12 microsatellite markers.

\begin{tabular}{|c|c|c|c|c|c|c|c|}
\hline Location & Coordinates & $\mathrm{N}$ & $\mathrm{Na}$ & $A r$ & Ho & $\mathrm{He}$ & $F_{I S}$ \\
\hline Rocha do Navio & $32^{\circ} 48^{\prime} 26^{\prime \prime} \mathrm{N} ; 16^{\circ} 51^{\prime} 35^{\prime \prime} \mathrm{W}$ & 23 & 10.00 & 5.91 & 0.59 & 0.79 & 0.28 \\
\hline Porto Moniz & $32^{\circ} 51^{\prime} 49^{\prime \prime} \mathrm{N} ; 17^{\circ} 09^{\prime} 51^{\prime \prime} \mathrm{W}$ & 22 & 9.16 & 5.84 & 0.53 & 0.77 & 0.33 \\
\hline Paúl do Mar & $32^{\circ} 45^{\prime} 49^{\prime \prime} \mathrm{N} ; 17^{\circ} 14^{\prime} 05^{\prime \prime} \mathrm{W}$ & 22 & 9.83 & 5.75 & 0,64 & 0.79 & 0.21 \\
\hline Garajau & $32^{\circ} 38^{\prime} 45^{\prime \prime} \mathrm{N} ; 16^{\circ} 53^{\prime} 15^{\prime \prime} \mathrm{W}$ & 22 & 9.50 & 5.97 & 0,57 & 0.79 & 0.31 \\
\hline Desertas & $32^{\circ} 30^{\prime} 22^{\prime \prime} \mathrm{N} ; 16^{\circ} 30^{\prime} 33^{\prime \prime} \mathrm{W}$ & 23 & 9.83 & 5.86 & 0,56 & 0.79 & 0.30 \\
\hline Porto Santo & $33^{\circ} 06^{\prime} 16^{\prime \prime} \mathrm{N}, 16^{\circ} 19^{\prime} 56^{\prime \prime} \mathrm{W}$ & 23 & 10.50 & 5.87 & 0,680 & 0.78 & 0.16 \\
\hline
\end{tabular}

\subsection{Population differentiation}

A power analysis was used to evaluate the power of the microsatellite markers used in this study to detect a signal of population differentiation. The test was carried out in POWERSIM 4.1 (Ryman and Palm 2006) assuming a population with $\mathrm{Ne} 2180$ (as estimated with DIYABC) at time $1,10,20,30,40,50,60,70,80,90$, and 100 , assuming 6 populations and 12 markers.

A $F_{S T}$ distance matrix created in GENALEX 6.5 (Peakall and Smouse 2006) was constructed to observe the genetic distance among $P$. aspera individuals from the 6 sampled locations. Genetic distance should reflect similarity and differences in the genetic composition of individuals from different locations, thus helping to infer the relationship between individuals within locations. Alternatively, population differentiation was evaluated using a Bayesian approach in the software STRUCTURE 2.34 (Pritchard et al., 2000; Hubisz et al., 2009). Runs were executed assuming an admixture model with correlated alleles frequencies for $k$ $=1$ to $k=\mathrm{n}+1$ ( $n=$ number of sampled locations and $\mathrm{k}=$ number of assumed clusters). Ten replicates were run for each $\mathrm{k}$ using burn-in = 200,000 and sampling steps $=1000,000$. Results were collected and assessed in STRUCTURE HARVESTER (Earl 2012) using the Evanno method (Evanno et al., 2005) to assess the most likely number of $k$, summarized using the greedy algorithm in CLUMPP 1.1.2 (Jakobsson and Rosenberg 2007). The final plot was obtained and edited with DISTRUCT version 1.1. (Rosenberg 2004).

\subsection{Long-term past and contemporary migration patterns}

Long-term past migrations were assessed using a Bayesian Markov Monte Carlo approach in the software MIGRATE-n (Beerli 2006, 2009) to estimate mutation-scaled migration rates $(M=m / \mu ; m$, probability of a lineage immigrating per generation; $\mu$, mutation rate). Thus, the main direction and magnitude of long-term past migrations for $P$. aspera populations in the archipelago of Madeira were calculated. In order to estimate the migration model reproducing the most likely migration scheme of the analysed populations, two models were assessed. The first model assumed a panmictic migration scheme; while a second model assumed a high unidirectional connectivity from Paul do Mar (SW Madeira) into all other sampling points (based on BAYESASS results). The two models were compared with the Bezier implementation in Migrate-n based on the log marginal likelihood of the posterior probabilities following Beerli and Palczewski (2010). Analyses were run with an increment of 100 , sampling 500,000 states with a burn-in of 50,000 states, and heating $1,1.5,3.0$, and 1000,000 . Priors included a uniform distribution with values 0,500 , and 0.1 for $\Theta$ and $0,50,000$, and 50 for $M$. All MIGRATE-n analyses were run in the CIPRES Science Gateway version 3.3 clusters (https://www.phylo.org). Recent migration rates were calculated in BAYESASS 3.0 (Wilson and Rannala 2003), identifying the gene flow signature from the current generation to up to two generations in the past. Four replicates with 10000,000 iterations were used, sampling every 1,000 samples with burn-in equal to 1000,000 , deltaA $=0.30$, and deltaF $=0.50$. Trace results were observed in Tracer (Rambaut et al., 2018) to identify that the probability of all parameters reached a plateau and that all parameters showed a smooth distribution.

\subsection{Approximate Bayesian Computation $(A B C)$ scenarios}

Three major events could explain the contemporary genetic patterns of $P$. aspera in the archipelago of Madeira. Although they have been hypothesized previously (e.g. Rijsdijk et al., 2014; Fernández-Palacios et al., 2016), they have not been evaluated using a genetic approach at a small scale. These events are: (i) a likely expansion or contraction of population between the end of the Pleistocene and the Holocene, including the LGM, (ii) the Portuguese colonization of Madeira six centuries ago with increased pressure on littoral resources, and (iii) the increase of the extraction of $P$. aspera during the last century. Two scenarios were evaluated using an Approximate Bayesian Computation in the software DIYABC 2.1 (Cornuet et al., 2014): (i) Scenario 1 considered a population scenario from a reduced $\mathrm{Ne}$ at time $\mathrm{t}_{3}$ to a higher $\mathrm{Ne}$ at time $\mathrm{t}_{2}$, and then an $\mathrm{Ne}$ that could remain constant or decrease, thus it could evaluate a possible effect human activity at time $t_{1}$ (with a range of time including recent extractions of $P$. aspera and human colonization; Fig. 2A), and (ii) Scenario 2 considering a reduction of $\mathrm{Ne}$ from a time $\mathrm{t}_{3}$ to a time $t_{2}$, and then an equal or minor $\mathrm{Ne}$ as consequence of human activity at time $\mathrm{t}_{1}(\mathrm{t} 1 \leq \mathrm{t} 2)$ (Fig. 2B). Simulations included a wide distribution of parameter values and reduced number of hypotheses to avoid our own bias and over-parameterization of the models. Hence, the ABC software was able to assess the potential effects of anthropogenic pressure (e.g. Portuguese colonization and harvesting) as well climatic events (e.g. Pleistocene glaciations, Last Glacial Maximum, and Younger Dryas) with a reduced bias from the authors. Scenarios were evaluated in DIYABC using 3000000 simulated data sets using the prior distribution shown in the Supplementary methods and Table 2.

\section{Results}

\subsection{Descriptive analyses}

Although 21-23 individuals were collected within each location, not all individuals were successfully amplified for the 13 polymorphic microsatellite markers developed for $P$. aspera by Faria et al. (2017). One marker ASP2F suffered from over 20\% of missing values among all 64 individuals amplified; therefore, it was not included in any of further analyses. Deviations from the Hardy Weinberg Equilibrium (HWE) were observed before and after using a Bonferroni correction, while not being linked to any particular location. Deviations were due to one marker (ASP38). No deviations from the Linkage Disequilibrium (LD) were observed at population nor marker level.

Number of alleles $\left(N_{a}\right)$ were generally similar among locations, ranging from 9.16 in Porto Moniz to 10.50 in Porto Santo, allelic 
A)

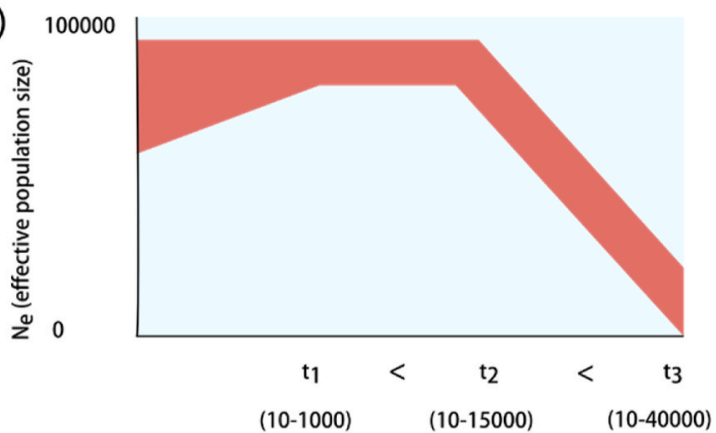

B)

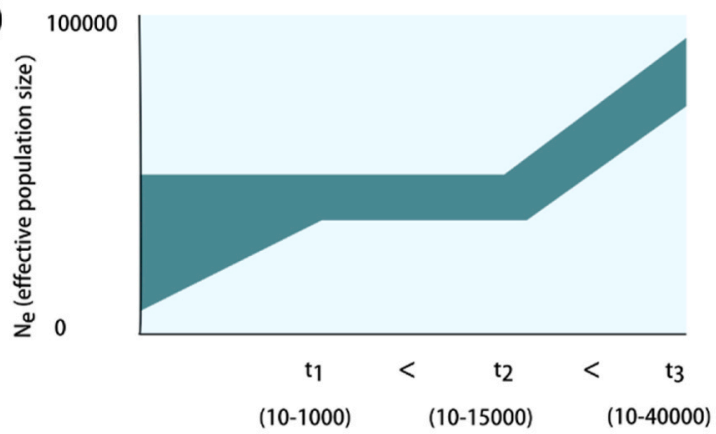

C)

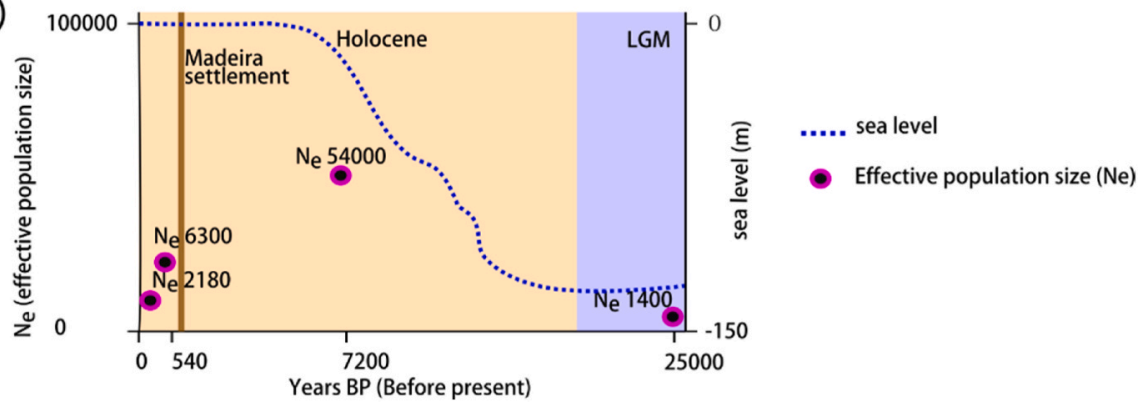

Fig. 2. Simulated scenarios in DIYABC for Scenario 1 (Fig. 2A), assuming a population expansion signal estimated as $N_{\mathrm{e}}$ (effective population size; 10-100000 lower and upper limit respectively for all simulated $N_{\mathrm{e}}$, shown in light blue) from the end of the Pleistocene ( $\mathrm{t}=10-40000$ generations) up to the Holocene ( $\mathrm{t}=10-15000$ generations) and maintenance or decrease of the $N_{\mathrm{e}}$ during the last thousand years $(\mathrm{t}=1000$ generations), and Scenario 2 (Fig. 2B), assuming a population contraction signal estimated as $N_{\mathrm{e}}$ (effective population size) from the end of the Pleistocene $(\mathrm{t}=10-40000$ generations) up to the Holocene ( $\mathrm{t}=10-15000$ generations) and maintenance or decrease of the $N_{\mathrm{e}}$ during the last thousand years $(\mathrm{t}=1000$ generations). Summarized posterior median values obtained from DIYABC are shown in Fig. $2 \mathrm{C}$ revealing an expansion signal (estimated as $N_{\mathrm{e}}$ ) from the Pleistocene up to the Holocene and a contraction of the $N_{\mathrm{e}}$ occurring after the Portuguese settlements of the archipelago of Madeira. $N_{\mathrm{e}}=$ effective population size, $\mathrm{t}=$ lower and upper limit of variable time (in brackets). (For interpretation of the references to colour in this figure legend, the reader is referred to the Web version of this article.)

Table 2

Prior and mean posterior distribution of parameters for two demographic scenarios for Patella aspera individuals from the Archipelago of Madeira using DIYABC. Median posterior values (including q0.025 - q0.975) are included for the most likely scenario (Scenario 1 ).

\begin{tabular}{|c|c|c|c|}
\hline \multirow[b]{2}{*}{ Parameter } & \multicolumn{2}{|l|}{ Scenario 1} & \multirow{2}{*}{$\frac{\text { Scenario } 2}{\text { Prior }}$} \\
\hline & Prior & Median posterior (q0.025 - q0.975) & \\
\hline $\mathrm{Ne}$ & $10-100000$ & $2630(450-7140)$ & $10-100000$ \\
\hline Net1 & $10-100000$ & $1310(354-1970)$ & $10-100000$ \\
\hline Net2 & $10-100000$ & $53700(8570-98000)$ & $10-100000$ \\
\hline Net3 & $10-100000$ & $3720(1010-9320)$ & $10-100000$ \\
\hline $\mathrm{t} 1$ & $10-1000$ & $538(480970)$ & $10-1000$ \\
\hline $\mathrm{t} 2$ & $10-15000$ & $7200(950-14500)$ & $10-15000$ \\
\hline $\mathrm{t} 3$ & $10-40000$ & $25000(7000-39000)$ & $10-40000$ \\
\hline
\end{tabular}

richness $\left(A_{\mathrm{r}}\right)$ ranged from 5.75 in Paul do Mar to 6.97 in Garajau (MPA), while private alleles ranged from 0.50 in Porto Moniz to 0.75 in Porto Santo (Table 1). Observed heterozygosity was lower in Porto Moniz (Ho $=0.53)$ and higher in Porto Santo $(H o=0.60)$. For all cases, expected heterozygosity $\left(H_{\mathrm{e}}\right)$ was higher than $H_{\mathrm{o}}$ (Table 1$)$. In every single comparison, $H$ e was higher than $H o$, and all $\mathrm{F}_{\mathrm{IS}}$ values were positive (Table 1).

\subsection{Past and contemporary migration patterns}

The Bezier method used for comparing the two migration schemes in MIGRATE-n suggested that the panmictic model was the best scenario explaining past migration patterns of $P$. aspera in the archipelago of Madeira ( $\mathrm{Ln}=-1618,364.78)$. Thus, long-term past migration pattern reconstructed in MIGRATE-n using a Bayesian approach revealed a mostly symmetrical connectivity during the past (Fig. 1A; Table S2), with $M(M=m / \mu)$ ranging from 48.2 (Paúl do Mar into Rocha do Navio) to 82.5 (Paúl do Mar into Desertas). Contemporary gene flow calculated in BAYESASS (Fig. 1B; Table S3) revealed a contrasting result to the observed in the long-term past migrations with a highly asymmetrical connectivity. High contemporary gene flow occurred from Paúl do Mar, on the Southwestern side of Madeira Island, into all other locations, ranging from 0.265 to 0.270 . Gene flow among individuals of all other five locations was mostly nil, ranging from 0.011 to 0.014 . The geographic position of Paúl do Mar where the ocean current turns into East of the archipelago, suggests that this population might be acting as a source of genetic variability by exporting individuals from this location into all other locations, a process that could be related with the timing of the reproduction of P. aspera from January to April (Fig. 1B).

\subsection{Population differentiation and gene flow}

The results from the power analyses revealed that the 12 microsatellite markers were able to detect an $F_{S T} 0.007$ with a $100 \%$ confidence (based on Chi and Fisher index; Table S4). Thus, the genetic variability described with the following statistics were reliable. $F_{S T}$-based genetic distances (Supplementary material, Table S5) ranged from 0.000 to 0.017 , revealing low differentiation among most of locations, except between Porto Santo and all other locations. Nevertheless, $F_{\mathrm{ST}}$ were significant only between Porto Santo and Paúl do $\operatorname{Mar}\left(F_{\mathrm{ST}}=0.017\right.$, pvalue $=0.018)$ and between Porto Santo and Garajau $\left(F_{\mathrm{ST}}=0.014\right.$, pvalue $=0.045$; Fig. $1 \mathrm{C}$ ), both locations located in the southern part of Madeira Island. The Evanno method, used to identify the most likely number of $k$ from STRUCTURE suggested $k=2$ (Figure S1), revealing a very subtle differentiation among individuals from Porto Santo (represented mostly in light blue) and all other five locations (represented in 
light blue and yellow), suggesting an emerging differentiation of the Porto Santo population (Fig. 1D). The Desertas Islands seemed to be more differentiated among the southern islands as suggested by the STRUCTURE plot (with a high presence of yellow bars). Thus, both analyses to estimate population differentiation suggested a subtle but existing differentiation between Porto Santo and all other locations.

\subsection{Approximate Bayesian Computation (ABC) scenarios}

The evaluation of the two simulated scenarios of the past genetic diversity, including a scenario with population expansion and likely effect of anthropogenic activity (Scenario 1; Fig. 2A), or population reduction and likely anthropogenic activity (Scenario 2; Fig. 2B). The direct method and logistic regression revealed that Scenario 1 was the most likely scenario explaining the contemporary genetic patterns of $P$. aspera in the archipelago of Madeira (Figure S2). Simulation results were assessed by model checking, revealing that the observed data were located within the distribution of the components of both scenarios (Figure S3). Results from DIYABC from Scenario 1 suggest a population expansion pattern occurring during the Holocene, with an effective population $(\mathrm{Ne})$ increase from 1400 at time t3 25000 years before present (BP) up to Ne 54000 at time t2 7200 years BP (Fig. 2C). The results from DIYABC also reveal a reduction of $N$ e up to 6300 at time $t_{1} 540$ years BP, a time coinciding with the beginning of the Portuguese settlements in the island. This reduction in Ne continued to nowadays (at time $\mathrm{t}_{0}$ ) until reaching $\mathrm{Ne}=2180$.

\section{Discussion}

Our results, discussed below, revealed the importance of population expansion during the Holocene as consequence of more favourable temperatures and more rocky habitat, the negative effects of anthropogenic pressure during the last six centuries and the importance of ocean currents interacting with the timing of the reproduction of the species to maintain the gene flow.

\subsection{Changes in the sea level during the quaternary and its importance to explain extant patterns of connectivity}

The archipelago of Madeira has experienced major changes in its coastal configuration and extent as well as in the connectivity between islands (i.e. Madeira and Desertas) since the end of the Pleistocene. By the end of the Pleistocene, during the LGM ( $c a$. 22,000 years BP), the sea level declined to its lowest level worldwide up to $120-130 \mathrm{~m}$ below the extant sea level. During this period, shallow coastal areas were exposed, increasing the surface of continental and island areas, as well as connecting some areas of the world through land bridges previously and currently non-existent (Clark and Mix 2002; Clark et al., 2009). The island of Porto Santo was five times larger than at present during the LGM. The present-day islands of Madeira and Desertas were joined into one island. The archipelago has been considered a glacial refugial area for marine coastal species as suggested by geological and phylogeographic studies (e.g. Domingues et al., 2007), with important implications for diversity in the wider north-east Atlantic region with subsequent post-glacial expansion. Marine species were affected by the Quaternary fluctuations of the sea level and the decrease in the temperature (Ludt and Rocha 2015; Ortego and Knowles, 2020; Stiller et al., 2021), especially coastal species whose habitat increased during the Holocene as consequence of the sea level decrease (Dolby et al., 2016) as occurred with different rocky shore species including mussels (Rawson and Harper 2009; Cunha et al., 2011), kelps (Fraser et al., 2009; Neiva et al., 2018), and limpets (de Aranzamendi et al., 2011; Mmonwa et al., 2015; Pardo-Gandarillas et al., 2018). The ABC approach revealed that $P$. aspera survived during the LGM within archipelago of Madeira despite the likely decrease in the sea surface temperatures. This has been previously hypothesized by biogeographic studies for other coastal species
(Rijsdijk et al., 2014; Fernández-Palacios et al., 2016). During the LGM (26500 years BP), the effective population size $\left(N_{\mathrm{e}}\right)$ of $P$. aspera was lower than at present, although still moderate to high when compared with that observed for other marine species such as the abovementioned i.e. mussels, kelps or other species of limpets. With the increase of the sea level and warming during the Holocene, the $N_{\mathrm{e}}$ of $P$. aspera increased up to 54,000 by 7200 years BP, most likely due to warming ocean conditions extending reproductive seasons and success and the availability of suitable rocky habitat. Then, 540 years BP, the ABC method revealed a decline in the $N_{\mathrm{e}}$ to 6,300 . This estimate of time could be related with the appearance of the Portuguese settlements in the archipelago of Madeira 580 years BP. P. aspera has been consumed in archipelago of Madeira for centuries (Silva and Menezes, 1921) and it is likely that the drop in the $N_{\mathrm{e}}$ obtained with the ABC method could be reflecting this pressure since colonization. Expected heterozygosities (He) were higher than $\mathrm{Ho}$ in all cases, with positive $F_{\text {IS }}$ values ranging from 0.16 to 0.33 , suggesting a lower heterozygosity than the expected within all locations. Lower heterozygosities could be the result of centuries of over-exploitation of $P$. aspera. These heterozygosities and $F_{\mathrm{IS}}$ are on the line with the results from DIYABC, supporting a negative effect of over exploitation pressure on $P$. aspera. Evidence exists of local extinction of other molluscs within archipelago of Madeira as occurred with nine species of land snails that became extinct during the last six centuries due to human consumption (Goodfriend et al., 1994). Anthropogenic island extinction is common worldwide due to the introduction of exotic species competing or predating with native species, human consumption, and habitat loss (Wood et al., 2017). Here we provide evidence that recovering genetic diversity during the Holocene was interrupted in $P$. aspera due to the extraction of individuals for consumption. These results also suggest that the Younger Dryas had no effect on the genetic diversity of $P$. aspera, suggesting that anthropogenic pressure had a higher influence on this species than other climatic events occurring between the late Pleistocene and the Holocene. This result is in line with previous studies suggesting a low impact of the Younger Dryas on the archipelago of Madeira, an area that probably acted as a glacial refugia for several Atlantic species (Domingues et al., 2007).

\subsection{Past and contemporary migration patterns and population boundaries}

Migrations estimated with Migrate-n revealed a high and mostly symmetric connectivity among islands within archipelago of Madeira at the LGM, a pattern coinciding with the high connectivity between Madeira and Desertas during the LGM and the existence of the Canary current. A high connectivity within the Macaronesian islands, from which archipelago of Madeira is part of, has been suggested as the best explanation for the existence of similar species within all the islands and high similarity (Ávila et al., 2008). For instance, a recent study by Faria et al. (2018) examined broadscale genetic structure of $P$. aspera in the Macaronesia, finding that populations from single locations in Madeira and Gran Canaria were well differentiated from the Azores. Our study reveals finer scale genetic patterns of $P$. aspera within the archipelago of Madeira.

Contemporary observations and ocean simulations have revealed that the Canary current shows seasonal changes, with a movement from West to East between January to March and North to South and East to West during the rest of the year (Stramma and Siedler 1988; Batteen et al., 2000). It is noteworthy that the reproduction of $P$. aspera within archipelago of Madeira from January to April matches the time when the Canary current moves from West to East, a pattern that could explain the observed contemporary asymmetric gene flow estimated with BAYESASS, where gene flow occurs from Paul do Mar in the West side of Madeira Island into all other parts of Madeira Island, Porto Santo and Desertas Islands. This high asymmetric gene flow could explain the observed patterns with the software STRUCTURE, where the most likely number of populations was estimated as $\mathrm{k}=2$, although the observed 
pattern suggests a high admixture and some degree of differentiation or homogenization between Porto Santo and all other locations. $F_{\mathrm{ST}}$ distances allowed to identify more details into this pattern, describing a low but significant differentiation between the southern localities from Madeira Island (Paul do Mar and Garajau) with Porto Santo.

\subsection{Conservation and resource management implications}

Here, by studying $P$. aspera individuals from six locations within the archipelago of Madeira, using a novel set of microsatellite markers, we found subtle signals of differentiation with two different approaches, $F_{\mathrm{ST}}$ and the software STRUCTURE. The apparent subtle differentiation and genetic diversity observed could be explained by the combined effect of spatiotemporal changes in the connectivity and anthropogenic effect. The changes in connectivity patterns described here, going from a highly symmetrical connectivity during the past to an asymmetric gene flow occurring from a single location via ocean currents nowadays could be of interest for conservation policies. For instance, Paúl de Mar, a location where $P$. aspera been highly harvested during the past shows a moderate genetic diversity and due to this and its importance as a source of variability for Madeira island, should be prioritized for conservation. Porto Santo shows the highest values of genetic diversity (Na, Ar, and Ho) and thus should be of interest for conservation as well. Among those localities where conservation measures are already ongoing due to the implementation of an MPA, we observed a moderate to high genetic diversity and thus, the status of these areas should be maintained. Nevertheless, no significant evidence of an increase in the genetic diversity was found in these areas when compared with other localities, mostly due to the time of the creation of MPAs (20 years). Of most concern is evidence of the contraction of effective population size of this species since first colonization which must have accelerated in recent years throughout the Madeiran, Canarian and Azorian archipelagos with population expansion and tourism (WTO, 2019).

\subsection{Caveats}

Some caveats need to be considered to avoid overinterpretation. For instance, sample size $(n=21-23)$ and number of markers $(n=12)$ were relatively small and thus this methodological aspect could influence the results. Nevertheless, the results of the power analysis reveal that the number of markers and sample size is more than enough to observe processes occurring at 30 or more generations in the past with a $100 \%$ confidence for $F_{\mathrm{ST}}$ as little as 0.007 . Although all Bayesian analyses were run for enough generations to obtain a good distribution of parameters it is known that some of the software used could lead to biased interpretations. For instance, Samarasin et al. (2017) found that combining the results from Migrate-n and BAYESASS could lead to inaccurate conclusions when used to estimate long-term and short-term past processes respectively. Nevertheless, in this study, all reconstructions (i.e. BAYESASS, Migrate-n, DIYABC, and bibliographical data) support each other, helping to arrange the pieces of the puzzling patterns of the evolutionary history of $P$. aspera.

\subsection{Concluding remarks}

Disentangling the mixed signal of evolutionary processes acting at different time scales by combining different Bayesian approaches and traditional analyses based on genetic markers have proven to be useful to better comprehend the history of species (Baguette et al., 2013; Epps and Keyghobadi 2015; Rissler 2016; Selkoe et al., 2016). Here, by using the limpet $P$. aspera inhabiting the archipelago of Madeira we have shown how natural events (Quaternary glaciations) and anthropogenic pressure (Portuguese settlement) have affected the genetic patterns of a species. Thus, the use of coalescent and $\mathrm{ABC}$ methods to assess hypotheses at different timescales can allow to understand the consequences of past processes and can be helpful for the conservation of species. For instance, the decrease of the $N_{\mathrm{e}}$ of the species in one third during six centuries is a warning sign not just about the past effects of humans on species, but also on the negative consequences that our species could generate with this littoral species and others in the future. Here, this study could help to lead conservation measures as the reduction of harvesting of the species, especially in the location acting as a source of variability for all other locations due to the here discovered combined effect of reproductive time and gene flow during a spatiotemporal change in the currents.

\section{Statement of significance}

Using a genetic approach, we observed that human pressure has serious effects on the genetic diversity of a highly-exploited intertidal mollusk. These effects have been steadily accelerating since the establishment of Portuguese in the XV century in Madeira.

\section{Data accessibility statement}

Microsatellite genotypes in Genepop, BayesAss, Migrate-n, and Structure were uploaded to https://figshare.com/s/1588b353400110 $80 \mathrm{e} 8 \mathrm{a} 8$.

\section{Declaration of competing interest}

The authors declare that they have no known competing financial interests or personal relationships that could have appeared to influence the work reported in this paper.

\section{Acknowledgements}

The authors are grateful to the Regional Directorate for the Sea (DSEIMar) of the Regional Directorate of Sea of the Autonomous Region of Madeira. The first author (RS) was supported by a grant from ARDITI OOM/2016/010 (M1420-01-0145-FEDER-000001-Observatório Oceânico da Madeira-OOM), the second author (JV) by a grant from Fundação para a Ciência e Tecnologia - FCT (SFRH/BSAB/143056/ 2018). This study was also supported by the UE FEDER in the framework of the Projects MARISCOMAC (MAC/2.3d/097) and MACAROFOOD (MAC/2.3d/015), the Regional Government of Madeira and by FCT, through the strategic project UID/MAR/04292/2019 granted to MARE. IV-E thanks FONDCYT 3190489.

\section{Appendix A. Supplementary data}

Supplementary data to this article can be found online at https://doi. org/10.1016/j.marenvres.2021.105485.

\section{References}

Al-Asadi, H., Petkova, D., Stephens, M., Novembre, J., 2019. Estimating recent migration and population-size surfaces. PLoS Genet. 15 (1), e1007908.

Allendorf, F.W., 2017. Genetics and the conservation of natural populations: allozymes to genomes. Mol. Ecol. 26 (2), 420-430.

Artamonov, Y.V., Kubryakov, A.I., Kuftarkov, A.Y., 1994. Hydrological conditions of water mass subduction in the eastern north Atlantic Ocean (cruise 43 of R/ VAkademik Verndsky). Phys. Oceanogr. 5 (4), 295-308.

Ávila, S.P., Madeira, P., Da Silva, C.M., Cachao, M., Landau, B., Quartau, R., Martins, A.d. F., 2008. Local disappearance of bivalves in the Azores during the last glaciation. J. Quat. Sci.: Publ. Quat. Res. Assoc. 23 (8), 777-785.

Baguette, M., Blanchet, S., Legrand, D., Stevens, V.M., Turlure, C., 2013. Individual dispersal, landscape connectivity and ecological networks. Biol. Rev. 88 (2), 310-326.

Bakare, A.G., Kour, G., Akter, M., Iji, P.A., 2020. Impact of climate change on sustainable livestock production and existence of wildlife and marine species in the South Pacific island countries: a review. Int. J. Biometeorol. 1-13.

Batteen, M.L., Martinez, J.R., Bryan, D.W., Buch, E.J., 2000. A modeling study of the coastal eastern boundary current system off Iberia and Morocco. J. Geophys. Res. Oceans 105 (C6), 14173-14195.

Beerli, P., 2006. Comparison of Bayesian and maximum-likelihood inference of population genetic parameters. Bioinformatics 22 (3), 341-345. 
Beerli, P., 2009. How to use MIGRATE or why are Markov chain Monte Carlo programs difficult to use. Populat. Genet. Anim. Conserv. 17, 42-79.

Beerli, P., Palczewski, M., 2010. Unified framework to evaluate panmixia and migration direction among multiple sampling locations. Genetics 185 (1), 313-326.

Boaventura, D., Fonseca, L.C., Hawkins, S.J., 2003. Size matters: competition within populations of limpet Patella depressa. J. Anim. Ecol. 72, 435-446.

Boehrer, G.C., 1955. The franciscans and Portuguese colonization in Africa and the Atlantic islands, 1415-1499. Americas 11 (3), 389-403.

Cheang, C.C., Tsang, L.M., Ng, W.C., Williams, G.A., Chu, K.H., Chan, B.K., 2012 Phylogeography of the cold-water barnacle Chthamalus challengeri in the northwestern Pacific: effect of past population expansion and contemporary gene flow. J. Biogeogr. 39 (10), 1819-1835.

Clark, P.U., Dyke, A.S., Shakun, J.D., Carlson, A.E., Clark, J., Wohlfarth, B., Mitrovica, J. X., Hostetler, S.W., McCabe, A.M., 2009. The last glacial maximum. Science 325 (5941), 710-714.

Clark, P.U., Mix, A.C., 2002. Ice sheets and sea level of the last glacial maximum. Quat. Sci. Rev. 21 (1-3), 1-7.

Cornuet, J.-M., Pudlo, P., Veyssier, J., Dehne-Garcia, A., Gautier, M., Leblois, R., Marin, J.-M., Estoup, A., 2014. DIYABC v2. 0: a software to make approximate Bayesian computation inferences about population history using single nucleotide polymorphism, DNA sequence and microsatellite data. Bioinformatics 30 (8), 1187-1189.

Crandall, E.D., Jones, M.E., Munoz, M.M., Akinronbi, B., Erdmann, M.V., Barber, P.H., 2008. Comparative phylogeography of two seastars and their ectosymbionts within the Coral Triangle. Mol. Ecol. 17 (24), 5276-5290.

Crandall, E.D., Treml, E.A., Liggins, L., Gleeson, L., Yasuda, N., Barber, P.H. Wörheide, G., Riginos, C., 2014. Return of the ghosts of dispersal past: historical spread and contemporary gene flow in the blue sea star Linckia laevigata. Bull. Mar. Sci. 90 (1), 399-425.

Cunha, R.L., Lopes, E.P., Reis, D.M., Castilho, R., 2011. Genetic structure of Brachidontes puniceus populations in Cape Verde archipelago shows signature of expansion during the last glacial maximum. J. Molluscan Stud. 77 (2), 175-181.

de Aranzamendi, M.C., Bastida, R., Gardenal, C.N., 2011. Different evolutionary histories in two sympatric limpets of the genus Nacella (Patellogastropoda) in the Southwestern Atlantic coast. Mar. Biol. 158 (11), 2405-2418.

Dolby, G.A., Hechinger, R., Ellingson, R.A., Findley, L.T., Lorda, J., Jacobs, D.K., 2016. Sea-level driven glacial-age refugia and post-glacial mixing on subtropical coasts, palaeohabitat and genetic study. Proc. Biol. Sci. 283 (1843), 20161571.

Dolby, G.A., Bedolla, A.M., Bennett, S.E., Jacobs, D.K., 2020. Global physical controls on estuarine habitat distribution during sea level change: consequences for genetic diversification through time. Global Planet. Change 187, 103128.

Domingues, V.S., Santos, R.S., Brito, A., Alexandrou, M., Almada, V.C., 2007. Mitochondrial and nuclear markers reveal isolation by distance and effects of Pleistocene glaciations in the northeastern Atlantic and Mediterranean populations of the white seabream (Diplodus sargus, L.). J. Exp. Mar. Biol. Ecol. 346 (1-2), 102-113.

Earl, D.A., 2012. Structure HARVESTER: a website and program for visualizing STRUCTURE output and implementing the Evanno method. Conserv. Genet. Resour. 4 (2), 359-361.

Ehlers, J., Gibbard, P.L., 2004. Quaternary Glaciations-Extent and Chronology: Part I: Europe. Elsevier.

Ehlers, J., Gibbard, P.L., Hughes, P., 2011. Quaternary Glaciations-Extent and Chronology: a Closer Look. Elsevier.

Epps, C.W., Keyghobadi, N., 2015. Landscape genetics in a changing world: disentangling historical and contemporary influences and inferring change. Mol. Ecol. 24 (24), 6021-6040.

Evanno, G., Regnaut, S., Goudet, J., 2005. Detecting the number of clusters of individuals using the software STRUCTURE: a simulation study. Mol. Ecol. 14 (8), 2611-2620.

Faria, J., Martins, G.M., Pita, A., Ribeiro, P.A., Hawkins, S.J., Presa, P., Neto, A.I., 2017. Disentangling the genetic and morphological structure of Patella candei complex in Macaronesia (NE Atlantic). Ecol. Evol. 7 (16), 6125-6140. https://doi.org/10.1002/ ece3.3121.

Faria, J., Pita, A., Martins, G.M., Ribeiro, P.A., Hawkins, S.J., Presa, P., Neto, A.I., 2018. Inbreeding in the exploited limpet Patella aspera across the Macaronesia archipelagos (NE Atlantic): implications for conservation. Fish. Res. 198, 180-188.

Fenderson, L.E., Kovach, A.I., Llamas, B., 2020. Spatiotemporal landscape genetics: investigating ecology and evolution through space and time. Mol. Ecol. 29 (2) 218-246.

Fernández-Palacios, J.M., Rijsdijk, K.F., Norder, S.J., Otto, R., de Nascimento, L., Fernández-Lugo, S., Tjørve, E., Whittaker, R.J., 2016. Towards a glacial-sensitive model of island biogeography. Global Ecol. Biogeogr. 25 (7), 817-830.

Fraser, C.I., Nikula, R., Spencer, H.G., Waters, J.M., 2009. Kelp genes reveal effects of subantarctic sea ice during the Last Glacial Maximum. Proc. Natl. Acad. Sci. Unit. States Am. 106 (9), 3249-3253.

Goodfriend, G.A., Cameron, R., Cook, L., 1994. Fossil evidence of recent human impact on the land snail fauna of Madeira. J. Biogeogr. 309-320.

Groom, M.J., Meffe, G.K., Carroll, C.R., Andelman, S.J., 2006. Principles of Conservation Biology. Sinauer Associates Sunderland.

Hernawan, U.E., van Dijk, K.j., Kendrick, G.A., Feng, M., Biffin, E., Lavery, P.S. McMahon, K., 2017. Historical processes and contemporary ocean currents drive genetic structure in the seagrass $T$ halassia hemprichii in the Indo-Australian archipelago. Mol. Ecol. 26 (4), 1008-1021.

Holderegger, R., Balkenhol, N., Bolliger, J., Engler, J.O., Gugerli, F., Hochkirch, A., Nowak, C., Segelbacher, G., Widmer, A., Zachos, F.E., 2019. Conservation genetics: linking science with practice. Mol. Ecol. 28 (17), 3848-3856.
Hubisz, M.J., Falush, D., Stephens, M., Pritchard, J.K., 2009. Inferring weak population structure with the assistance of sample group information. Mol. Ecol. Resour. 9 (5), 1322-1332.

Imron, Jeffrey B., Hale, P., Degnan, B.M., Degnan, S.M., 2007. Pleistocene isolation and recent gene flow in Haliotis asinina, an Indo-Pacific vetigastropod with limited dispersal capacity. Mol. Ecol. 16 (2), 289-304.

Jakobsson, M., Rosenberg, N.A., 2007. CLUMPP: a cluster matching and permutation program for dealing with label switching and multimodality in analysis of population structure. Bioinformatics 23 (14), 1801-1806.

Jones, M.C., Cheung, W.W., 2018. Using fuzzy logic to determine the vulnerability of marine species to climate change. Global Change Biol. 24 (2), e719-e731.

Kalinowski, S.T., 2005. hp-rare 1.0: a computer program for performing rarefaction on measures of allelic richness. Mol. Ecol. Notes 5 (1), 187-189.

Lambeck, K., Rouby, H., Purcell, A., Sun, Y., Sambridge, M., 2014. sea level and global ice volumes from the last glacial maximum to the Holocene. Proc. Natl. Acad. Sci. Unit. States Am. 111 (43), 15296-15303.

Lind, C.E., Evans, B.S., Taylor, J.J., Jerry, D.R., 2007. Population genetics of a marine bivalve, Pinctada maxima, throughout the Indo-Australian archipelago shows differentiation and decreased diversity at range limits. Mol. Ecol. 16 (24), 5193-5203.

Ludt, W.B., Rocha, L.A., 2015. Shifting seas: the impacts of Pleistocene sea-level fluctuations on the evolution of tropical marine taxa. J. Biogeogr. 42 (1), 25-38.

Mairal, M., Sanmartín, I., Aldasoro, J.J., Culshaw, V., Manolopoulou, I., Alarcón, M., 2015. Palaeo-islands as refugia and sources of genetic diversity within volcanic archipelagos: the case of the widespread endemic C anarina canariensis (C ampanulaceae). Mol. Ecol. 24 (15), 3944-3963.

Marko, P.B., Hoffman, J.M., Emme, S.A., McGovern, T.M., Keever, C.C., Nicole Cox, L., 2010. The 'Expansion-Contraction'model of Pleistocene biogeography: rocky shores suffer a sea change? Mol. Ecol. 19 (1), 146-169.

Miller, K.J., Ayre, D.J., 2008. Population structure is not a simple function of reproductive mode and larval type: insights from tropical corals. J. Anim. Ecol. 77 (4), 713-724.

Mmonwa, K.L., Teske, P., McQuaid, C., Barker, N., 2015. Historical demography of southern African patellid limpets: congruence of population expansions, but no phylogeography. Afr. J. Mar. Sci. 37 (1), 11-20.

Muñoz-Ramírez, C.P., Barnes, D.K., Cárdenas, L., Meredith, M.P., Morley, S.A., RomanGonzalez, A., Sands, C.J., Scourse, J., Brante, A., 2020. Gene flow in the Antarctic bivalve Aequiyoldia eightsii (Jay, 1839) suggests a role for the Antarctic Peninsula coastal current in larval dispersal. Roy. Soc. Open Sci. 7 (9), 200603.

Neiva, J., Paulino, C., Nielsen, M.M., Krause-Jensen, D., Saunders, G.W., Assis, J, Bárbara, I., Tamigneaux, É., Gouveia, L., Aires, T., 2018. Glacial vicariance drives phylogeographic diversification in the amphi-boreal kelp Saccharina latissima. Sci. Rep. 8 (1), 1-12.

Ngeve, M.N., Van der Stocken, T., Menemenlis, D., Koedam, N., Triest, L., 2016. Contrasting effects of historical sea level rise and contemporary ocean currents on regional gene flow of Rhizophora racemosa in Eastern Atlantic mangroves. Plos One 11 (3), e0150950.

Nuryanto, A., Kochzius, M., 2009. Highly restricted gene flow and deep evolutionary lineages in the giant clam Tridacna maxima. Coral Reefs 28 (3), 607-619.

Ortego, J., Knowles, L.L., 2020. Incorporating interspecific interactions into phylogeographic models: a case study with Californian oaks. Mol. Ecol. 29, 4510-4524.

Pardo-Gandarillas, M.C., Ibáñez, C.M., Torres, F.I., Sanhueza, V., Fabres, A., EscobarDodero, J., Mardones, F.O., Méndez, M.A., 2018. Phylogeography and species distribution modelling reveal the effects of the Pleistocene ice ages on an intertidal limpet from the south-eastern Pacific. J. Biogeogr. 45 (8), 1751-1767.

Patiño, J., Carine, M., Mardulyn, P., Devos, N., Mateo, R.G., González-Mancebo, J.M., Shaw, A.J., Vanderpoorten, A., 2015. Approximate Bayesian computation reveals the crucial role of oceanic islands for the assembly of continental biodiversity. Syst. Biol. 64 (4), 579-589.

Peakall, R., Smouse, P.E., 2006. Genalex 6: genetic analysis in Excel. Population genetic software for teaching and research. Mol. Ecol. Notes 6 (1), 288-295.

Pecl, G., Ward, T., Doubleday, Z., Clarke, S., Day, J., Dixon, C., Frusher, S., Gibbs, P., Hobday, A., Hutchinson, N., 2011. Risk assessment of impacts of climate change for key marine species in South Eastern Australia. Part 2, p. 479.

Pirazzoli, P.A., 1997. Sea-level changes: the last 20000 years. Oceanogr. Lit. Rev. 8 (44), 785.

Portnoy, D., Hollenbeck, C., Belcher, C., Driggers III, W., Frazier, B., Gelsleichter, J., Grubbs, R., Gold, J., 2014. Contemporary population structure and post-glacial genetic demography in a migratory marine species, the blacknose shark, Carcharhinus acronotus. Mol. Ecol. 23 (22), 5480-5495.

Pritchard, J.K., Stephens, M., Donnelly, P., 2000. Inference of population structure using multilocus genotype data. Genetics 155 (2), 945-959.

Rambaut, A., Drummond, A.J., Xie, D., Baele, G., Suchard, M.A., 2018. Posterior summarization in Bayesian phylogenetics using Tracer 1.7. Syst. Biol. 67 (5), 901.

Rawson, P.D., Harper, F.M., 2009. Colonization of the northwest Atlantic by the blue mussel, Mytilus trossulus postdates the last glacial maximum. Mar. Biol. 156 (9), 1857-1868.

Riginos, C., Liggins, L., 2013. Seascape genetics: populations, individuals, and genes marooned and adrift. Geogr. Compass 7 (3), 197-216.

Rijsdijk, K.F., Hengl, T., Norder, S.J., Otto, R., Emerson, B.C., Ávila, S.P., López, H., van Loon, E.E., Tjørve, E., Fernández-Palacios, J.M., 2014. Quantifying surface-area changes of volcanic islands driven by Pleistocene sea-level cycles: biogeographica implications for the Macaronesian archipelagos. J. Biogeogr. 41 (7), 1242-1254.

Rissler, L.J., 2016. Union of phylogeography and landscape genetics. Proc. Natl. Acad. Sci. Unit. States Am. 113 (29), 8079-8086. 
Rosenberg, N.A., 2004. DISTRUCT: a program for the graphical display of population structure. Mol. Ecol. Notes 4 (1), 137-138.

Rousset, F., 2008. genepop'007: a complete re-implementation of the genepop software for Windows and Linux. Mol. Ecol. Resour. 8 (1), 103-106.

Russell-Wood, A., 2007. Settlement, colonization, and integration in the Portugueseinfluenced world, 1415-1570. Port. Stud. Rev. 15 (1-2), 1-36.

Ryman, N., Palm, S., 2006. POWSIM: a computer program for assessing statistical power when testing for genetic differentiation. Mol. Ecol. Notes 6 (3), 600-602.

Sá-Pinto, A., Branco, M., Sayanda, D., Alexandrino, P., 2008. Patterns of colonisation, evolution and gene flow in species of the genus Patella in the Macaronesian islands. Mol. Exol. 17, 519-532.

Samarasin, P., Shuter, B.J., Wright, S.I., Rodd, F.H., 2017. The problem of estimating recent genetic connectivity in a changing world. Conserv. Biol. 31 (1), 126-135.

Scavia, D., Field, J.C., Boesch, D.F., Buddemeier, R.W., Burkett, V., Cayan, D.R., Fogarty, M., Harwell, M.A., Howarth, R.W., Mason, C., 2002. Climate change impacts on US coastal and marine ecosystems. Estuaries 25 (2), 149-164.

Scheltema, R., 1971. Dispersal of phytoplanktotrophic shipworm larvae (Bivalvia: Teredinidae) over long distances by ocean currents. Mar. Biol. 11 (1), 5-11.

Selkoe, K.A., Aloia, C.C., Crandall, E.D., Iacchei, M., Liggins, L., Puritz, J.B., von der Heyden, S., Toonen, R.J., 2016. A decade of seascape genetics: contributions to basic and applied marine connectivity. Mar. Ecol. Prog. Ser. 554, 1-19.

Silva, F.A., Menezes, C.A., 1921. Elucidário Madeirense - 1 Volume A-E. Tipografia Esperança (Funchal).

Sousa, R., Delgado, J., Pinto, A.R., Henriques, P., 2017. Growth and reproduction of the north-eastern Atlantic keystone species Patella aspera (Mollusca: Patellogastropoda). Helgol. Mar. Res. 71 (1), 1-13.

Sousa, R., Vasconcelos, J., Henriques, P., Pinto, A.R., Delgado, J., Riera, R., 2019. Longterm population status of two harvested intertidal grazers (Patella aspera and Patella candei), before (1996-2006) and after (2007-2017) the implementation of management measures. J. Sea Res. 144, 33-38.

Sousa, R., Vasconcelos, J., Riera, R., Pinto, A.R., Delgado, J., Henriques, P., 2019a. Potential impact of harvesting management measures on the reproductive parameters of the limpets Patella aspera and Patella candei from Madeira Island. Estuarine. Coast Shelf Sci. 226, 106264.

Sousa, R., Vasconcelos, J., Riera, R., Pinto, A.R., Delgado, J., Henriques, P., 2019b. Potential impact of harvesting management measures on the reproductive parameters of the limpets Patella aspera and Patella candei from Madeira Island. Estuarine. Coast Shelf Sci. 226, 106264.

Stange, C.A., Sánchez-Villagra, M.R., Salzburger, W., Matschiner, M., 2018. Bayesian divergence-time estimation with genome-wide single-nucleotide polymorphism data of sea catfishes (Ariidae) supports Miocene closure of the Panamanian Isthmus. Syst. Biol. 67 (4), 681-699.

Stiller, J., da Fonseca, R.R., Alfaro, M.E., Faircloth, B.C., Wilson, N.G., Rouse, G.W., 2021. Using ultraconserved elements to track the influence of sea-level change on leafy seadragon populations. Mol. Ecol. 30, 1364-1380.

Stramma, L., Siedler, G., 1988. Seasonal changes in the North Atlantic subtropical gyre. J. Geophys. Res.: Oceans 93 (C7), 8111-8118.

Vera-Escalona, I., Habit, E., Ruzzante, D.E., 2015. Echoes of a distant time: effects of historical processes on contemporary genetic patterns in Galaxias platei in Patagonia. Mol. Ecol. 24 (16), 4112-4128.

Waltari, E., Hickerson, M.J., 2013. Late Pleistocene species distribution modelling of North Atlantic intertidal invertebrates. J. Biogeogr. 40 (2), 249-260.

Wang, I.J., 2010. Recognizing the temporal distinctions between landscape genetics and phylogeography. Mol. Ecol. 19 (13), 2605-2608.

Weber, L.I., Hawkins, S.J., 2002. Evolution of the limpet Patella candei d'Orbigny (Mollusca, Patellidae) in Atlantic archipelagos: human intervention and natural processes. Biol. J. Linn. Soc. 77, 341-353.

Weber, L.I., Thorpe, J.P., Santos, R.S., Hawkins, S.J., 1998. Identification of stocks of the exploited limpets Patella aspera and $P$. candei at Madeira Archipelago by allozyme electrophoresis. J. Shellfish Res. 17, 945-953.

Weigelt, P., Steinbauer, M.J., Cabral, J.S., Kreft, H., 2016. Late Quaternary climate change shapes island biodiversity. Nature 532 (7597), 99-102.

Wilson, G.A., Rannala, B., 2003. Bayesian inference of recent migration rates using multilocus genotypes. Genetics 163 (3), 1177-1191.

Wood, J.R., Alcover, J.A., Blackburn, T.M., Bover, P., Duncan, R.P., Hume, J.P., Louys, J., Meijer, H.J., Rando, J.C., Wilmshurst, J.M., 2017. Island extinctions: processes, patterns, and potential for ecosystem restoration. Environ. Conserv. 44 (4), 348-358. World Tourism Organization, 2019. Panorama OMT del turismo internacional.

Zhou, M., Paduan, J.D., Niiler, P.P., 2000. Surface currents in the Canary Basin from drifter observations. J. Geophys. Res. 105, 21893-21911. 